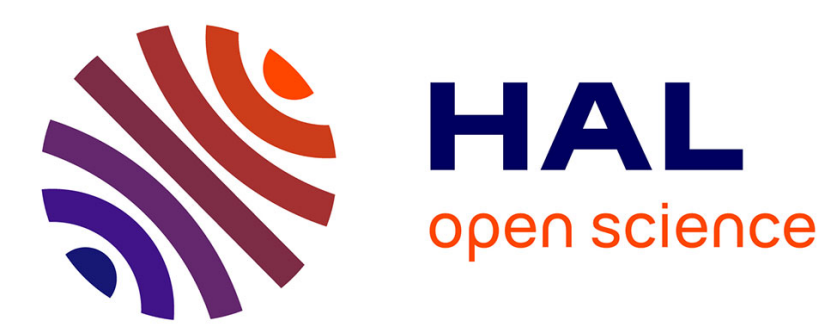

\title{
The links between openness and productivity in Mediterranean countries
}

Cecchini Laurence, Lai-Tong Charles

\section{To cite this version:}

Cecchini Laurence, Lai-Tong Charles. The links between openness and productivity in Mediterranean countries. Applied Economics, 2008, 40 (06), pp.685-697. 10.1080/00036840600749771 . hal00582023

\section{HAL Id: hal-00582023 \\ https://hal.science/hal-00582023}

Submitted on 1 Apr 2011

HAL is a multi-disciplinary open access archive for the deposit and dissemination of scientific research documents, whether they are published or not. The documents may come from teaching and research institutions in France or abroad, or from public or private research centers.
L'archive ouverte pluridisciplinaire HAL, est destinée au dépôt et à la diffusion de documents scientifiques de niveau recherche, publiés ou non, émanant des établissements d'enseignement et de recherche français ou étrangers, des laboratoires publics ou privés. 


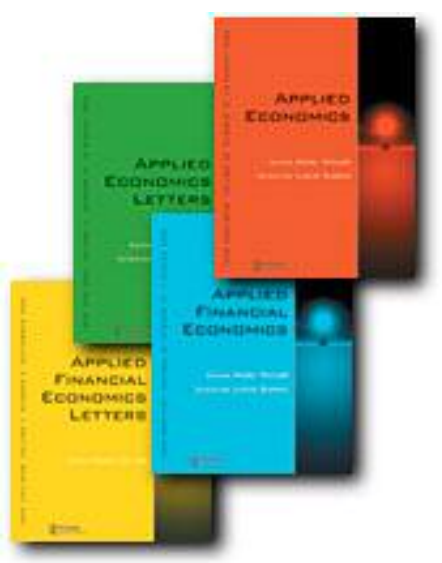

The links between openness and productivity in Mediterranean countries

\begin{tabular}{|c|c|}
\hline Journal: & Applied Economics \\
\hline Manuscript ID: & APE-05-0668 \\
\hline Journal Selection: & Applied Economics \\
\hline $\begin{array}{r}\text { Date Submitted by the } \\
\text { Author: }\end{array}$ & 29-Nov-2005 \\
\hline JEL Code: & $\begin{array}{l}\text { F43 - Economic Growth of Open Economies < F4 - Macroeconomic } \\
\text { Aspects of International Trade and Finance < F - International } \\
\text { Economics, O47 - Measurement of Economic Growth|Aggregate } \\
\text { Productivity < O4 - Economic Growth and Aggregate Productivity < } \\
\text { O - Economic Development, Technological Change, and Growth }\end{array}$ \\
\hline Keywords: & $\begin{array}{l}\text { mediterranean countries, direct investment, openness, productivity, } \\
\text { human capital }\end{array}$ \\
\hline
\end{tabular}




\title{
The links between openness and productivity in Mediterranean countries
}

\author{
LAURENCE CECCHINI*`, CHARLES LAI-TONG** \\ * CEFI, Université de la Méditerranée et IUFM de Lyon, France \\ ** CEFI, Université de la Méditerranée, France
}

We examine the relation between the international trade, the foreign direct investment and the total factor productivity of the Mediterranean partner countries of Europe within the framework of a cointegrated panel model.

The results, obtained from data on seven Mediterranean partner countries of Europe (Algeria, Egypt, Israel, Jordan, Morocco, Tunisia, Turkey), show that FDI and human capital are complementary in the acquisition of productivity gains. We identify the threshold level of human capital from which the received foreign investments generate beneficial effects.

In a more general way, the improvement of the total factor productivity via the international openness results only from the indirect effects related to the transfer of technology.

\section{INTRODUCTION}

Many theoretical arguments bring support to the idea that foreign direct investment and international trade promote development in partner countries of Europe from eastern and southern parts of the Mediterranean ${ }^{1}$ (hereinafter, PM countries).

First, FDI flows are, just like trade flows, an integral part of the process of opening up a country's economy. Both trade and FDI flows are considered as opportunities to boost economic activity. International trade allows the various countries to increase their productivity because it allows them to specialize according to their comparative advantages. FDI flows increase the capital stock and, therefore contribute to productivity improvements because previously unemployed resources are likely to be absorbed within the economic system and existing resources are likely to find a more productive use. FDI also spurs competition and therefore leads to a better resource allocation. Second, recent advances in endogenous growth theory put the stress on the crucial importance of research and development ${ }^{2}$ and human capital ${ }^{3}$ for growth. According to this view, international trade and FDI flows are considered as vectors allowing the diffusion of technical progress.

A number of empirical studies have confirmed the existence of a positive relationship between growth, or total factor productivity, and the following explanatory variables: R\&D, trade openness, human capital and FDI, whether they enter the equation separately or in a combined way. Because they shed light on the

\footnotetext{
- Corresponding author. Postal address: 5, impasse de la Combe, 30133 Les Angles. 1cecchini@wanadoo.fr.
} 
transmission channels, and because they claimed that the benefits from international trade and FDI were universal, most papers from the 90s have fuelled the wave of trade liberalization policies in many developing countries (DC's). As to international trade, Coe and Helpman (1995) show that total factor productivity (hereafter TFP) in a given country depends not only on its domestic R\&D stock, but also on the R\&D stock of its trade partners ${ }^{4}$. They show that the more open the country, the more important the relative role played by foreign R\&D with respect to domestic R\&D. Krueger (1997) strongly supports trade liberalization in DC's: comparing exports growth to GDP growth, she finds that the most open countries are, in the long run, also those who record the most impressive growth performances. As far as FDI is concerned, Finlay (1978) suggests that it boosts technical progress in the host country thanks to a "contagion effect" from more advanced technologies, from better management practices, and so on...in set up firms. Wang (1990) incorporates this idea in a model in which applied knowledge in production is a function of FDI. On the empirical side, a study led by UNCTAD (1992) concludes that FDI has a major role to play as a key engine of growth in DGC's. Blomstrom, Lipsey and Zejan (1992) reach the same conclusion. Besides, the respective performances of FDI and of domestic investment have already been compared in a number of papers. In particular, De Gregorio (1992) studies 12 countries from Latin America and reports that FDI is three times more efficient than domestic investment.

However, another strand of the literature, that takes into account various specificities of DC's, such as the nature of their specialization pattern (Choudhri and Hakura, 2000) or the qualification level of the workforce (Borensztein, De Gregorio and Lee, 2000), comes to less rosy conclusions regarding the role of trade and foreign capital openness. This is at odds with the vast majority of the studies conducted on developed countries. That strand of the literature, which is recent, emphasizes that the debate about the impact of international trade and FDI's on development, is still not closed.

Can the PM countries enjoy the beneficial effects of openness, and in particular of FDI, which do not seem to show up automatically? On what conditions could these effects be strengthened?

Our goal is thus to study how the various theories and induced relationships between international trade, FDI and growth can be applied and specified to the case of PM countries. As far as total factor productivity adequately measures the efficiency of the production process and therefore plays a key role in development, our analysis will focus on TFP. In a first stage, we use a Cobb-Douglas production function to estimate the TFP of seven Mediterranean countries (Algeria, Egypt, Israel, Morocco, Tunisia, Turkey). Next, we investigate into the determinants of these TFP's in the way that was suggested by Coe and Helpman (1995) 
while incorporating the contributions of Lichtenberg and Van Pottelsberghe (1998) and of De Gregorio and Lee (1998). Our empirical analysis uses a panel data setup and our sample covers the period 1980-2000.

The present study is organized as follows. In Section 2, we explain the theoretical relationships between FDI and TFP and confront these relationships to the actual situation in PM countries. In Section 3, we present our model and we present our results regarding the impact of FDI and of other explanatory variables on TFP. Section 4 concludes and presents various policy implications.

\section{THEORETICAL RELATIONSHIPS BETWEEN INTERNATIONAL TRADE, FDI AND DEVELOPMENT, AND COMPARISON WITH THE ACTUAL SITUATION IN DC'S.}

The benefits from free trade have been emphasized not only by traditional trade theory but also by the new approaches, that incorporate imperfect competition features. Some papers, however, cast somehow some doubt on the beneficial impacts from trade liberalization on development in DC's. Greenaway, Morgan and Wright (2002) make use of three different measures of liberalization ${ }^{5}$ and test a dynamic growth model on alternative DC samples. They conclude that the beneficial impact of trade liberalization on per capita GDP may happen but its size remains limited and it occurs with a time lag. Choudhri and Hakura (2000) put the stress on the importance of the nature of specialization in DC's: as far as the comparative advantage of DC's probably lies in traditional sectors with low growth perspectives, unregulated international trade might restrict production to such sectors and eventually lead to lower productivity growth ${ }^{6}$. Relying upon the "technological gap" model of Krugman $(1990)^{7}$, they conduct an empirical analysis on 33 DC's and conclude that the stiffening of competition through higher imports promotes growth and global productivity only when this stiffening takes place in medium-growth industries. In traditional industries (characterized by slower growth), as well as in high-tech sectors, a rise in imports has no impact on global productivity growth.

A lot is expected regarding the impact of FDI on development in PM countries because, in these countries, international trade failed to initiate a strong and positive comparative advantage dynamics.

There are various ways, either direct or indirect ones, through which FDI may have an impact:

- FDI inflows raise the available capital stock in the host country. Therefore, they allow to make up for the weakness of domestic savings, a reason that is often invoked to justify second-rate performances. However, Reis (2000) emphasizes the fact that FDI may be repatriated. His model, that builds upon Grossman and Helpman (1991, chap. 4), incorporates not only the technological effect, i.e. the fact that it becomes less costly to introduce a new good in the host country's economy since technology is already known, but also the 
drain effect, i.e. the negative impact stemming from the repatriation of the income generated by the investment. The total effect on a small country's wealth depends upon the relative weights of these two components.

- FDI flows are less volatile than portfolio investments. First, the process leading to an investment decision is rather lengthy as compared to the process giving rise to the purchase of a bond. FDI decisions come after foregoing detailed country and sector analyses, and this to an even larger extent than bank loans. Second, as far as FDI are concerned, the relevant lag between the decision to invest and the actual funds transfers is in months. A single FDI decision can give birth to financial flows spread over several years, if the purchase of capital or the investment in the production process occurs in multiple stages. Third, an FDI is seldom an isolated flow. It is, in general, part of a global investment strategy in a country or in a zone and there are heavy entry or exit costs. These features distinguish FDI flows from portfolio investments, for which transaction costs remain limited. This relative stability of FDI is, as such, beneficial for the development of the host country.

- $\quad$ FDI may have a positive impact on domestic investment They appear as catalysts for technical progress and domestic investments by creating external complementarity effects (Bourgain and Pierreti, 1998). They complement domestic resources and send a trust signal about investment opportunities. However, in this case, the converse effect may arise: a contrario, FDI may produce a crowding out effect. If the foreign investment occurs in a branch in which domestic firms are already active, the crowding out effect may appear for two reasons: on the one hand, harsher competition may discourage more domestic firms from entering the market or drive the less efficient ones out of the market and on the other hand, the interest rate is likely to rise if foreign firms call on to the local capital markets. If FDI occurs in a new activity branch, the only relevant mechanism is the second one, which makes the crowding-out effect less likely.

Many recent studies focus on these negative impacts on domestic investments. According to UNCTAD (1999), the crowding-out effect appears in some countries from Subsaharian Africa and Latin America. Agosin and mayer (2000) formulate a theoretical model in which the impact of FDI on domestic investment are allowed to vary according to the country under consideration, according to the domestic policies that are pursued, according to the nature of FDI flows (i.e. in existing activities or in new activities) and according to the sector, depending on the technology: if the FDI takes place in a high-tech industry, it is expected to be complementary to domestic investment whereas if the FDI generates direct competition for existing local firms, first-degree substitution is expected. The authors use a panel of 32 DC's over the period 1970-1996 to 
test their model. They detect a positive impact of FDI on domestic investment in Asia ("crowding-in effect") and a negative impact in Latin America ("crowding-out effect"). As far as Africa is concerned, the effect is neutral.

- FDI is also expected to trigger growth because it spurs competition. The arrival of new competitors on the market should incite local firms to rationalize and modernize their production structure. As domestic firms increase productivity, foreign multinational corporations (FMC's) invest more and more as to keep up with their technological advantage (Glass and Saggi, 1998). Nevertheless, from a sector-based point of view, FDI may lead to a decrease in domestic firms' TFP: if foreign companies gain a large share of the domestic market, scale economies will decrease for domestic competitors. In the event that the sector in which competition from these foreign firms takes place is among the most dynamic ones, then even global TFP is likely to decrease. That argument is one point of convergence between this paper and the debate about infant industries' protection.

- The most widely expected impact from FDI upon growth stems from technology transfers. Incoming FDI into the host country has positive impacts since:

- FDI fosters the use of new intermediary goods. Therefore, an increase in the number of available varieties of intermediate goods or a deeper specialization of each one of them will result in an increase in production.

- In the same vein, technical assistance to local suppliers compels these to adapt to foreign standards in terms of quality and of delay.

- FDI also increases the overall knowledge stock of the host country thanks to local staff training and thanks to skill acquisition by the active population.

$\circ$ FDI permits the adoption of new management and organization paradigms.

○ Most generally, tacit knowledge spreads more easily with FDI than with imports.

Technology diffusion through FDI has received comparatively less attention than through international trade. This is due, in particular, to the scarcity of reliable data in that matter. As far as international trade is concerned, researchers have come to a common conclusion regarding the significant role of trade in knowledge spillovers, even though they used disparate methods and even though their quantitative results differ $^{8}$. Regarding FDI, there is no consensus whatsoever, not even at the qualitative level. Hejazi and Safarian (1999), among others, come to the conclusion that, over the same period, the spillover effects from the six largest developed countries towards smaller countries are rather important. Conversely, Lichtenberg 
and Van Pottelsberghe $(1998,2001)$, as well as Xu and Wang (2001), conclude that incoming FDI flows did not allow technology transfers among OECD countries over the period 1970-1990. Lichtenberg and Van Pottelsberghe (2001) make a distinction between incoming and outgoing FDI flows as sources of technology transfers and find that transfer through FDI is a one-way process: a given country increases its productivity if it invests in foreign R\&D-intensive countries but if it receives investments from $R \& D$ intensive countries. This result, though in sharp contrast with the vast majority of studies in that field that turn on developed countries, is consistent with the OLI paradigm set out by Dunning (1994). According to that paradigm, firms prefer to invest abroad, rather than to export, in order to take advantage of their technological lead, and not in order to diffuse that lead abroad. Xu (2000) finds that technology transfers from US multinational corporations has contributed to productivity growth in developed countries but not in less developed economies. Sadik and Bobol $(2001)^{9}$ reach similar conclusions. They distinguish between two effects triggered by FDI: on the one hand, it increases the available capital stock in the host country and, on the other hand, it may alter the efficiency of capital through the diffusion of technical progress. On the basis of a sample of six Arab countries, they come to the conclusion that, though FDI indeed contribute to the increase in the capital stock, it does not bring efficiency gains in the use of this capital stock: if there is a significantly positive link between growth and investment for all the countries in the sample, the link between FDI and growth appears significant and negative for three countries in the sample.

Moreover, technology diffusion appears to be limited to limited parts of the economy only. Yu and Demurger (2002), while studying the Chinese industry, find that the positive impact of FDI on economic growth shows up only in the consumption goods sector, and is invisible in the case of intermediary and equipment goods.

Finally, Borensztein, De Gregorio and Lee $(1998)^{10}$ put to the fore the conditional nature of the positive impact of incoming FDI. Their study relies on a sample of 69 DC's and reveals a strong complementarity between FDI and human capital. The positive impact of FDI shows up only if the human capital level in the host country reaches some minimal threshold. If the human capital stock is too low, the impact of FDI on growth is even negative. Human capital, together with available physical capital, determine the extent to which an economy will be able to absorb new technologies (which refers to accumulation theories). Nelson and Pack (1999) go one step further and add the innovation capacities within the population (assimilation theories), even though these are difficult to measure: entrepreneurship and risk-taking attitude. These features were put forward by Shumpeter and are considered as important factors when it comes to assimilate the technologies spread by FDI. 
The analysis shows that the technology transfer induced by the FDI will be more intensive as the spread between the imported technologies and the domestic technologies becomes more important and as the capability to absorb these new and complex technologies increases ${ }^{11}$.

The aforementioned literature leads us to question the automatic nature of the beneficial effects from FDI. In the light of this literature, it seems reasonable to assume that TFP in PM countries should benefit more from FDI as foreign firms do not compete "too strongly" with local producers, as the absorption capabilities to FDI- and trade-driven technology transfers are high, and in particular as the labor force is skilled. Do these latter features show up in PM countries?

\section{THE DETERMINANTS OF TFP IN MEDITERRANEAN COUNTRIES}

\section{III.1. Estimating TFP}

TFP is a core concept that lies in the heart of economic growth. Productivity growth is the source of a better life for future generations. Productivity also affects the competitiveness of a country: the more it is productive, the more it will be able to compete in international markets. To measure TFP growth, one divides output growth by a weighted average of growth in production factors utilization. To perform the calculation, it is very common to assume a Cobb-Douglas production function and to set the weight of each factor to its share in total costs. Although this method rests on restrictive assumptions ${ }^{12}$, it remains the less biased one. Therefore, we estimate TFP in the following way:

$$
\operatorname{TFP}_{t}=Y_{t} /\left(K^{\beta}{ }^{(1-\beta)}\right)
$$

with TFP is total factor productivity,

$\mathrm{Y}$ is the output,

$\mathrm{K}$ is the capital stock

$\mathrm{L}$ is labor

$\mathrm{t}$ is a time index

$\beta$ is the capital share in factors' reward

We estimated TFP for Mediterranean countries on the basis of their total GDP. Data for GDP and active population (as a number of persons, since total employment and unemployment rate are very poorly measured) are drawn from World Development Indicators 2003 from the World Bank. GDP is measured in constant 1987 prices, for sake of compatibility with capital data. The fixed capital stock was obtained from 
Nehru and Dhareshwan's database, that was published by the World bank from 1980 to 1990. Data for subsequent years result from an extrapolation performed by ourselves on the basis of WDI data on gross fixed capital formation. TFP is converted into an index with the normalization TFP $=1$ in 1995 .

The parameter $\beta$ varies across countries but remains stable across the period under investigation. For each country, we have fixed its level on the basis of previous studies ${ }^{13}: 0.22$ for Morocco (cf. Zaimi (2002)) ; 0.16 for Egypt and 0.25 for Tunisia (cf. Bouioiyour and Yazidi (2000)) ; 0.25 for Turkey (cf. Menegaldo (2001)) and we fix $\beta$ in Jordan at the same level as in Morocco.

Productivity gains are presented in Table 1, whereas we display the evolution of this variable in graphical form in Figure 1.

Our TFP results are consistent with figures produced in other research papers on PM countries ${ }^{14}$. Generally speaking, TFP evolves in an irregular fashion. This reflects the lack of stability of these economies, that are highly dependent on oil prices, on weather conditions (for example, in Morocco, TFP decreases during the droughts of 1989, 1992 and 1995), and on social or geo-political events.

Looking at the period as a whole, productivity gains prove important in three countries only: Egypt, Tunisia and Turkey. Regarding Israel and Morocco, productivity gains remain limited and the average yearly growth rate is below $1 \%{ }^{15}$. Finally, TFP decreases in Algeria and Jordan over the period 1980-2000.

\section{III.2. Theoretical models of references}

Our study builds on two kinds of approaches:

1. On the one hand, the papers by Coe and Helpman (1995) and by Lichtenberg and Van Pottelsberghe (1998). These papers investigate the link between technology transfers and outward orientation, through international trade for the former and through FDI for the latter.

2. On the other hand, the paper by Borensztein, De Gregorio and Lee (1998), which focuses on the role of human capital in technology transfers.

These papers rely upon new theoretical models of growth, that are already widely discussed in the literature so that there is no need to discuss them in the present work. Some particularly relevant references are Grossman and Helpman (1991), Helpman (1992), Romer (1990), and Barro and Sala-i-Martin (1995).

Coe and Helpman (1995) have shown that TFP in a given country depends not only on its own capital accumulation through $R \& D$, but also on the $R \& D$ stock of its trade partners. If a given country imports all its intermediate goods, the basic relationship between TFP and R\&D accumulation that was put forward by 
endogenous growth models remains valid, except that the relevant R\&D measure is not the domestic stock anymore but well the world stock. As, in practice, only a fraction of intermediate goods is imported, TFP differences are explained by domestic and foreign R\&D stocks altogether. Coe and Helpman suggest to take into account both the level of imports and their structure, i.e. the share of the various partner countries, for the computation of the foreign R\&D stock. Therefore,

$$
\log \operatorname{TFP}_{i}=\alpha_{i}+\alpha_{i}^{d} \log S_{i}^{d}+\alpha_{i}^{f} m_{i} \log S_{i}^{f}
$$

Where $S_{i}^{f}=\sum_{j \neq i} \frac{M_{i j}}{M_{i}} S_{j}^{d}$

$\mathrm{i}$ and $\mathrm{j}$ are country indexes

TFP is total factor productivity

$S^{d}$ is the domestic capital R\&D stock

$S^{f}$ is the foreign capital R\&D stock

$m_{i}$ is the imports share of GDP in country $i$

$\alpha^{d}$ is TFP elasticity with respect to domestic R\&D stock

$\alpha_{i}^{f} m_{i}$ is TFP elasticity with respect to foreign R\&D stock

$\mathrm{M}_{\mathrm{ij}}$ are imports of in country $\mathrm{i}$ coming from country $\mathrm{j}$.

Lichtenberg and Van Pottelsberghe $(1998,2001)$ extend Coe and Helpman's work in two main directions. On the one hand, they identify an "aggregation bias" in the computation of foreign R\&D stocks made by previous authors. Instead, they propose an alternative measure, for which the theoretical bias is less severe, and that yields better empirical results ${ }^{16}$. On the other hand, their econometric results show that FDI is indeed a vector that permits cross-border technology transfers. Their main contribution consists in testing the previous equation using various measures of the foreign R\&D stock. Two of these measures are particularly fit for our purposes in the present paper. Thus, the estimated equation is:

$$
\log \operatorname{TFP}_{i}=\alpha_{i}+\alpha_{i}^{d} \log S_{i}^{d}+\alpha_{i}^{f} \log S_{i}^{f}
$$

Where $S_{i}^{f}$ is computed in the two following ways:

$$
S_{i}^{f 1}=\sum_{j \neq i} \frac{M_{i j} S_{j}^{d}}{Y_{j}} ; \quad S_{i}^{f 2}=\sum_{j \neq i} \frac{f_{i j} S_{j}^{d}}{k_{j}}
$$

They introduce both measures simultaneously in the equation. The first measure is associated to the foreign R\&D stock that is embedded into imports, whereas the second one represents the foreign $R \& D$ stock that is 
embedded into FDI inflows. The identification of the source countries for imports helps to alleviate the “aggregation bias" since R\&D efforts agreed by the various trade partners are weighted by their exports level. FDI from country $j$ to country $i$, which we note $f_{i j}$, are weighted by gross fixed capital formation in country $j$, $\mathrm{k}_{\mathrm{j}}{ }^{17}$

Borensztein, De Gregorio and Lee (1999) focus on the impact of FDI on economic growth. Their empirical study covers 69 developing countries over both the $80 \mathrm{~s}$ and the $90 \mathrm{~s}$. The theoretical foundation for this paper lies in an endogenous growth model in which the main engine of long-run growth is the technical progress that in generated by the introduction of new varieties of capital goods. Multinational corporations enjoy a technological lead and bring in intermediate goods into the cost country at lower costs. However, these advanced technologies cannot be put into practice if the human capital stock in the host country is not high enough. Like in the papers by Nelson and Phelps (1966) or by Benhabib and Spiegel (1994), the human capital stock provides a bound for the absorption capability in developing countries. Using an illustrative model that is conceptually close of the one derived by Barro and Sala-i-Martin (1995, chap. 6), they test various versions of the following basic relationship:

$$
\mathrm{g}=\mathrm{c}_{0}+\mathrm{c}_{1} \quad \mathrm{FDI}+\mathrm{c}_{2} \quad \mathrm{FDI} \times \mathrm{H}+\mathrm{c}_{3} \quad \mathrm{H}+\mathrm{c}_{4} \quad \mathrm{Y}_{0}+\mathrm{c}_{5} \mathrm{~A}
$$

where $\mathrm{g}$ is the income growth rate

FDI is the flow of FDI originating from OECD countries

$\mathrm{H}$ is the human capital stock, as measured by the initial average years of schooling of men in secondary school. This indicator was proposed by Barro and Lee (1993).

$\mathrm{Y}_{0}$ is the initial GDP par capita

A is a set of other variables that are likely to affect economic growth and that are often included as determinants of growth in cross-country studies ${ }^{18}$.

\section{III.3 Applying The Model To Mediterranean Countries}

FDI data can be obtained from various sources. Both the World Bank (through its World Development Indicators) and the IMF (through its International Financial Statistics) provide statistics about net and incoming FDI flows. The OECD produces mode detailed data regarding FDI in member countries and even in some DC's. In particular, the source countries are identified, which could allow to weight FDI inflows by the R\&D stock in the source country. There are two drawbacks, however. On the one hand, among the southern 
and eastern Mediterranean countries, only Algeria, Turkey, Egypt and Morocco are available as partner countries. On the other hand, many data are missing for these countries. Therefore, we prefer to rely on World Bank data in order to have a better coverage of the Mediterranean area.

Compared with the theoretical arguments above, we simplify somewhat the empirical model and neglect the domestic R\&D stock. Indeed, in most developing countries, R\&D expenditures are negligible. We therefore assume they are low enough as to be ignored ${ }^{19}$. In a first stage, we test the basic equation (1) that contains a trade openness indicator, FDI and a human capital measure. Next, in equation (2), we integrate the R\&D conveyed by FDI. Finally, in order to test whether FDI impact on TFP is positively correlated to human capital, we estimate equation (3) that includes an interaction tem between both variables.

The estimated equations are as follows:

$$
\begin{aligned}
& \log \operatorname{TFP}_{\mathrm{it}}=\alpha_{\mathrm{i}}+\alpha^{\mathrm{fdi}} \mathrm{FDI}_{\mathrm{it}}+\alpha^{\text {open }} \mathrm{OPEN}_{\mathrm{it}}+\alpha^{\mathrm{e}} \mathrm{E}_{\mathrm{it}}+\varepsilon_{\mathrm{it}} \\
& \log \operatorname{TFP}_{\mathrm{it}}=\alpha_{\mathrm{i}}+\alpha^{\mathrm{fdi}} \mathrm{FDI}_{\mathrm{it}}+\alpha^{\mathrm{sr}} \mathrm{SR}_{\mathrm{it}}+\alpha^{\text {open }} \mathrm{OPEN}_{\mathrm{it}}+\alpha^{\mathrm{e}} \mathrm{E}_{\mathrm{it}}+\varepsilon_{\mathrm{it}} \\
& \log \text { TFP }_{\text {it }}=\alpha_{i}+\alpha^{\text {fdi }} \text { FDI }_{\text {it }}+\alpha^{\text {efdi }} \text { FDI }_{\text {it }} E_{i t}+\alpha^{\text {open }} \text { OPEN }_{i t}+\alpha^{e} E_{i t}+\varepsilon_{i t}
\end{aligned}
$$

Where $\mathrm{i}$ and $\mathrm{t}$ are indexes for Mediterranean countries and yearly time periods

TFP is total factor productivity

FDI is foreign direct investment

SR is the foreign capital R\&D stock embodied into imports

OPEN is the degree of openness, as measured by the classical ratio of total imports and exports to GDP
E is the secondary schooling rate
$\alpha_{i}$ is a country-specific intercept
$\varepsilon$ is the error term

Data sources, as well as the econometric methodology are described below.

FDI flows are net incoming flows expressed as percentages of GDP from WDI 2003. They indicate the share of foreign firms in the country's total production.

R\&D data for OECD countries are drawn from Basic Statistics of Technology and Science, by the OECD.

These are the various countries' total expenses in R\&D (DIRD) (in 1995 \$). The use of an alternative method, 
based on the investment expenses on R\&D made by the firms (DIRDE), yields similar results.

Missing values were interpolated assuming the average yearly growth rate between two periods for which data are available is constant. End-of-period missing values were filled in assuming the average yearly growth rate is constant and identical to the one obtained for the 5 last available years.

R\&D stocks for OECD countries were computed using the permanent inventory method. The stock at time $t$ is equal to the new expenses made at $\mathrm{t}$, plus the stock in (t-1) from which we have removed the depreciation. Thus:

$$
\mathrm{SRD}_{\mathrm{t}}=\mathrm{I}_{\mathrm{t}}+(1-\delta) \mathrm{SRD}_{\mathrm{t}-1}
$$

The initial stock is computed on the basis of the assumption that the average yearly growth rate of past investments is constant:

$$
\operatorname{SRD}_{t}=I_{t}+(1-\delta) \lambda I_{t}+(1-\delta)^{2} \lambda^{2} I_{t}+(1-\delta)^{3} \lambda^{3} I_{t}+\ldots
$$

Therefore,

$$
\operatorname{SRD}_{t}=\frac{\mathrm{I}_{t}}{1-\left(\frac{1}{1+r_{t}}\right)(1-\delta)}
$$

where $S R D_{t}$ is the $R \& D$ stock at time $t$

$I_{t}$ are the investment expenses on $R \& D$ at time $t$

$r_{t}$ is the average yearly growth rate of $I_{t}$

$\delta$ is the depreciation rate (assumed to be constant over the estimation period)

The depreciation rate is usually estimated between $5 \%$ and $15 \%$. We decide to set it at an intermediary level, at $10 \%$.

The 21 OECD countries taken into account are: Australia, Austria, Belgium, Canada, Denmark, Finland, France, Germany, Greece, Ireland, Iceland, Italy, Japan, The Netherlands, New Zealand, Norway, Portugal, Spain, Sweden, United Kingdom, and The United States of America.

The weights are computed on the basis of imports into PM countries (indexed by i) originating from each OECD country (indexed by $\mathrm{j}$ ), the data being provided by the CEPII on its CHELEM data, as:

$$
\frac{M_{i j}}{\sum_{j} G D P}
$$

where both the numerator and the denominator are un current US dollars. 
The degree of outward orientation of PM countries is measured by ratio between imports and exports of manufactured goods to GDP:

$$
\text { OPEN }=\frac{X+M}{G D P} * 100
$$

Both imports and exports are provided by the CHELEM database and all variables are in current dollars.

Educational data, E, correspond to the secondary schooling rate, expressed in percentage. They are provided by WDI 2003. If data were missing between two dates, we assumed that the yearly growth rate was constant between the available dates. In the case of end-of-period (2000) missing data, we supposed a constant rate over the last 10 available years. This is the most relevant indicator for PM with long time series. We introduced alternative human capital measures, such as tertiary schooling rate and the percentage of tertiary students in engineering or scientific subjects ; these variables appeared only as weakly significant. The number of students in secondary school yields results that similar to those obtained with the secondary schooling rate. Other indicators, such as the number of scientists or engineers in R\&D activities are very poorly measured in PM countries and thus cannot be used.

Since data about the source country in FDI are unavailable for most PM countries, we cannot compute the R\&D stock embodied into FDI. Foreign R\&D stocks are computed, for each Mediterranean country, as the imports-weighted sums of R\&D stocks within the 21 OECD countries. The weighting scheme is the same as the one used by Lichtenberg and Van Pottelsberghe de la Potterie, which we have presented supra.

Like Coe and Helpman (1995), Lichtenberg and Van Pottelsberghe (1998), or Kao, Chiang and Chen (1999), we seek for a cointegration relationship between our variables. Our empirical analysis occurs in 3 stages. First, we test for unit roots using the panel unit roots tests designed by Im, Pesaran and Shin (2003). Our results are presented in tables 2 and 3 and show that all variables are non-stationary and integrated of order 1. Next, we look for cointegration relationships. To do this, we implement the panel cointegration tests from Pedroni (1999). Finally, since data do not reject the null of cointegration, we estimate the long-run coefficients for equations (1) to (3). Table 4 presents our estimations, which we performed using the FM-OLS program from Pedroni (2000). In fact, the FM-OLS (Fully Modified OLS) estimator by Phillips and Hansen (1990) allows to correct possible biases that may arise in the estimation of a long-run relationship due to the endogenous nature of the regressors. Pedroni (2000) proposes a modified version of the traditional FM-OLS estimator that is adapted to cointegrated panel data sets by allowing heterogeneity regarding short-term dynamics and fixed effects. He reports good performances for his "group means FM-OLS" estimator, even in 
small samples.

Table 4 has very interesting implications as to the impact of FDI on TFP in PM countries. In regression (1), FDI have a positive impact on TFP, but is not significant. Introducing the interaction variable between FDI and human capital in equation (3) shows the unavoidable complementarity of both variables in the acquisition of productivity gains. This interaction term allows, moreover, to distinguish two different effects: while the coefficient on FDI is significant and negative, the coefficient on the interaction variable is also significant, but positive. Which means that technology transfers do have on impact on TFP in PM countries, and that this impact is positive only if the labor force is sufficiently skilled. On the other hand, other mechanisms, and in particular competition effects, may lead to a drop in investment and in output in dynamic sectors ( cf. Section II ), thereby causing a drop in global TFP in the host country.

Point estimates for the coefficients in regression (3) indicate FDI will have positive impacts for all countries displaying a secondary schooling rate above $55 \%^{20}$, since the former effect dominates the latter. All countries within our sample, at the exception of Morocco, are above that threshold in $2000^{21}$. This is even true since the beginning of the period for Israel, since the mid-80s for Egypt and Algeria, and since the mid-90s for Tunisia, Turkey and Jordan ${ }^{22}$. For instance, in an economy with secondary schooling rate around $80 \%$, a $1 \%$ increase in the FDI/GDP ratio boosts TFP by $1.1 \%$.

The analysis of trade flows leads to similar conclusions. In equation (1), trade in manufactures has a positive impact on TFP, as suggested by the theoretical literature. However, when we include R\&D embodied in imports in equations (2) and (3), we are able to distinguish across two trade-related effects : on the one hand, openness has a negative impact on TFP, whereas on the other hand, technology transfers, that are spread through imports, have a clearly positive indirect impact. A plausible explanation for the negative impact of international trade can base on the nature of trade and of specialization. Importing some goods can prove harmful for the competitiveness of domestic firms. Competition from foreign products prevents the domestic production of technological goods, such as equipment goods, from expanding. Consequently, resources tend to reallocate towards low-tech, slowly growing industries and towards services, which tends to deteriorate overall productivity.

Clearly, according to equations (2) and (3), the R\&D from OECD countries that is embedded into imports has a positive impact on TFP. Our conclusions on this point are similar to those reached by Coe and Helpman (1995), Coe, Helpman and Hoffmaister (1997), or Lichtenberg and Van Pottelsberghe (1998) on the basis of different country samples. Regarding our sample, we find that a $1 \%$ increase in imported R\&D expense 
generates a $0.14 \%$ (equation (2)) or a $0.15 \%$ (equation (3)) increase in TFP.

Lastly, in equations (1) to (3), the coefficient associated to human capital appears significant and positive, which confirms results from endogenous growth theory. It is possible to criticize the secondary schooling rate as indicator of human capital, because providing education to people does not imply that they will enter the active population, or that their skills will be adapted to the needs of the economy. Nevertheless, this secondary schooling rate provides a measure of the effort made by a nation to improve its human capital stock. This effort was considerable in the case of PM countries. Another argument that pleads in favor of the use of a metrics based on secondary schooling runs as follows: secondary schooling brings general basic skills that allow people to adapt to the needs of the firms. In equation (3) an increase in schooling by one percentage point increases TFP in PM countries by some $0.2 \%$.

In the end, our results indicate that, for the time being and for our country sample as a whole, the positive impact of technology transfers more than compensate the negative effects of trade openness.

\section{CONCLUSION}

Most of the time, international trade seems to strengthen inter-industry trade and therefore does not seem able to trigger a development dynamics in Mediterranean countries. More generally, improvements in total factor productivity though openness, either to trade or to FDI, result most of the time from the indirect effects, which stem from technology transfers.

It is possible to design fiscal policy measures intended to increase the global attraction potential for FDI. However, as the present paper shows, one should take into account the fact that such measures are costly and that they may divert public resources for projects that do not generate enough positive externalities as to justify their implementation. It seems preferable to resort to a more targeted strategy, geared towards industries that are likely to generate positive externalities and to foster technology transfers.

In that view, multinational corporations could contribute to technology transfers by adopting long-run strategies, by seeking the exploitation of dynamic comparative advantages through integration within activities with higher value added, by the introduction of new production methods that would be more efficient and more knowledge-intensive. In the same time, exports-oriented multinational corporations could expand progressively their ties with local suppliers in Mediterranean countries, thereby improving their integration into Mediterranean economies. This process of integration should benefit both sides since exports would become long-lasting and local firms would become more productive. The remaining task for local 
stakeholders is to create auspicious conditions for such projects through, in particular, an improvement in the business climate.

Moreover, more efforts should be made regarding the qualification of the workforce since absorption capabilities are a prerequisite to the acquisition of new technologies. These efforts should, from now on, bear more on the qualitative side than on the quantitative side. For local governments, the goal is to set their educational priorities according to industrial needs and to available resources. For their European partners, the goal is to reach a deeper level of cooperation, especially in the education field.

Technical progress spreads across the borders through international trade and though FDI. The beneficial impacts from this process do exist. They must, nevertheless, still be expanded. 
FIGURE 1 EVOLUTION OF TFP IN PM COUNTRIES (1995=1; Authors' calculations)
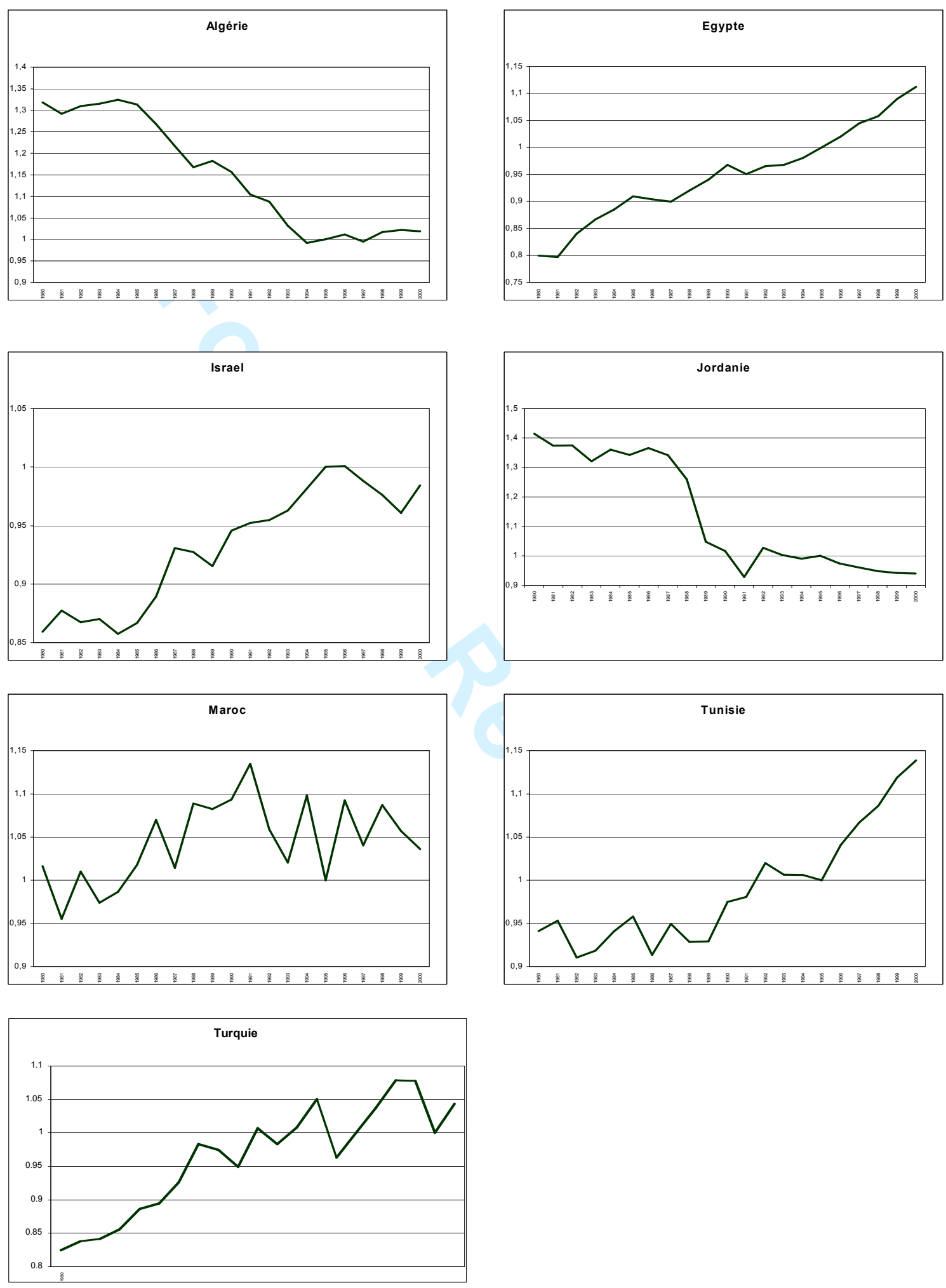


\section{TABLES}

Table 1 : Yearly TFP growth Rate, GDP-Based Measure, 1980-2000 (\%)

\begin{tabular}{|l|c|c|}
\cline { 2 - 3 } \multicolumn{1}{c|}{} & Average & Std. Deviation \\
\hline Algeria & -1.25 & 2.30 \\
\hline Egypt & 1.68 & 1.63 \\
\hline Israël & 0.69 & 1.78 \\
\hline Jordan & -1.88 & 5.17 \\
\hline Morocco & 0.23 & 5.38 \\
\hline Tunisia & 0.99 & 2.66 \\
\hline Turkey & 1.26 & 3.95 \\
\hline
\end{tabular}

Table 2. Panel Unit Root tests

\begin{tabular}{|l|c|c|}
\hline & Level & First-Difference \\
\hline LPTF & 1.292 & -4.782 \\
\hline FDI & 1.308 & -7.142 \\
\hline FDI*E & 3.937 & -5.793 \\
\hline LSR & -0.552 & -4.545 \\
\hline OPEN & -0.267 & -3.330 \\
\hline E & 3.735 & -1.391 \\
\hline
\end{tabular}

Im, Pesaran et Shin (2003) test, w-tbar statistics. Regarding the variables in levels, all w-tbar statistics are above the critical value -1,645. Thus, at the 5\% level, one cannot reject the null of a unit root for all variables.

Table 3. Panel Cointegration Tests

\begin{tabular}{|l|c|c|c|}
\hline & Model (1) & Model (2) & Model (3) \\
panel PP & -2.224 & -2.999 & -2.708 \\
panel ADF & -1.970 & -2.530 & -2.725 \\
& & & -4.898 \\
group PP & -2.931 & -4.713 & -4.438 \\
\hline group ADF & -2.577 & -3.682 & \\
\hline
\end{tabular}

Pedroni's (1999) tests were performed using his RATS program. The four test statistics are below -1.645, which leads us to reject the absence of cointegration for all 3 models.

Table 4. Estimation by FM-OLS of models (1) and (2)
(1)
(2)
(3)

\begin{tabular}{lccc}
\hline FDI & 0.017 & 0.001 & $-0.024^{*}$ \\
FDI*E & $(1.126)$ & $(0.408)$ & $(-2.469)$ \\
& & & $0.044^{*}$ \\
OPEN & & & $(2,707)$ \\
& $0.007^{*}$ & $-0.001^{*}$ & $-0.0009^{*}$ \\
LSRD & $(2.520)$ & $(-4.035)$ & $(-3.378)$ \\
& & $0.140^{*}$ & $0.149^{*}$ \\
E & & $(11.315)$ & $(12.580)$ \\
& $0.008^{*}$ & $0.003^{*}$ & $0.002 *$ \\
\hline
\end{tabular}

All variables are in deviation from time-means, which amounts to including common year dummies into the panels. T-ratios are between brackets, and * indicates signifiance at the 1\% level. 


\section{FOOTNOTES}

${ }^{1}$ Maghreb (Algeria, Tunisia, Morocco), Mashrek (Egypt, Jordan, Lebanon, Syria, Palestine), Turkey, Israel, Cyprus and Malta.

${ }^{2}$ Romer (1990) and Grossman and Helpman (1995) proposed the first theoretical models.

${ }^{3}$ Lucas (1988), among others, builds a model that clarifies the role of human capital accumulation for growth.

${ }^{4}$ Their work can be seen as an extension of the research carried by Griliches (1988) and Coe and Helpman (1993) on the positive impact of domestic R\&D accumulation on productivity.

${ }^{5}$ The first indicator is a variable that captures interventions by the World Bank. The second one is inspired by Dean et. al. (1994) and takes into account 4 elements: tariffs, quotas, exports subsidies and impediments, and exchange-rate misalignments. The third indicator is the one derived by Sachs and Warner (1995), that takes five criteria into account: the scope of tariff-free products, the average tariff rate, the black market premium, the tact that the economy is socialist-ruled or not and the existence of a State monopoly on main exports. The conclusions of this paper remain unchanged whatever the indicator in use.

${ }^{6}$ Endogenous growth theory considers this possibility. Grossman and Helpman (1991, chap. 18 and 19) set out several cases where free trade leads to lower productivity growth in technologically backward countries.

${ }^{7}$ There are three sectors, and each of them has its own constant rate of technical progress (one sector has slow technical progress, another one has medium technical progress and the third one has fast technical progress). Least developed countries have access to the best technologies, but with a longer time lag. They have, therefore, a comparative disadvantage in those sectors where productivity growth is the strongest. The idea according to which international trade facilitates technological transfers is incorporated through the assumption that the technological gap of a given country in a given sector is inversely related to the openness rate in that sector. Long-run overall TFP growth rate is the production-weighted average of sector growth rates.

${ }^{8}$ For example, Coe and Helpman (1995) find that investment in R\&D from OECD countries creates some $30 \%$ additional income for other OECD countries (which is well above the income impact of domestic R\&D investment), through an increase in their TFP. According to Bernstein and Mohnen (1998), R\&D spillovers from the USA towards Japan is well above those from Japan towards the USA.

${ }^{9}$ Their study covers Oman, Morocco, Seoudi Arabia, Jordan, Tunisia and Egypt over the period 1978-1998. It worth mentioning, though it is often the case, that the explanatory power of their equations is rather weak.

${ }^{10}$ They find that a positive impact of FDI on growth only appears when the capital stock is above 0.52 years 
of secondary school for adults. They compute the average education level as follows: if $10 \%$ of the adults above 25 reached the secondary school level and if $75 \%$ completed the full 6 -years cycle whereas the remaining completed the first 3 years, the secondary school level is: $0.1(6 * 0.75+3 * 0.25)=0.52$.

${ }^{11}$ See Sjoholm (1999) for the technology spread and Nelson and Pack (1999) about absorption capability.

${ }^{12}$ First, constant returns to scale are assumed, so that one attributes to TFP what should perhaps be attributed to externalities. However, choosing a production function that displays increasing or decreasing returns to scale requires to give a correct value to the parameter driving returns to scale, which seems no less restrictive. Second, capital stock estimates are even less reliable for DC's that they are for developed countries. Finally, in connection with the previous argument, TFP measures are highly sensitive to the share of each factor in value added. Therefore, we relied on previous work about PM countries to get an estimate of labor and capital share.

${ }^{13}$ Senhadji (2000) weights labor by human capital in order to get his labor share. He then obtains weaker $\beta$ coefficients. However, quality-adjusted labor series à la Senhadji are only available for the period 1960-1994 and are very tricky to construct. Therefore, we prefer to work directly on the basis of employment. Qualification will be incorporated later in our regressions on TFP determinants.

${ }^{14}$ In particular, the aforementioned papers, which make use of data sources partly different from ours.

${ }^{15}$ Average yearly growth rates, which are close from the average of yearly growth rates, amount to $0.46 \%$ for Morocco and $0.36 \%$ for Israel.

${ }^{16}$ Keller (1998) also strongly criticized the measure put forward by Coe and Helpman: using random weights for trade partners, he obtains more foreign technology diffusion effects and a better fit in terms of $\mathrm{R}^{2}$.

17 The authors obtained similar results when they replaced gross fixed capital formation of country $\mathrm{j}$ by its GDP.

${ }^{18}$ These variables are government consumption, the black market premium, a measure of political instability, a measure of political freedom, a proxy for development level of the financial system, the inflation rate, and a measure of the quality of institutions.

19 The number of data available for Mediterranean countries is, anyway, very low. This makes the construction of domestic R\&D stocks series particularly tricky and difficult.

${ }^{20}$ In the building of the interaction variable FDI $x \mathrm{E}$, the schooling rate is not expressed as a percentage, in order to get a coefficient whose order of magnitude can be compared to the coefficient on FDI.

${ }^{21}$ Again, one should be aware of both the advantages and drawbacks of the schooling rate as a proxy for 
human capital.

${ }^{22}$ More precisely, this level was reached in 1984 by Egypt, in 1987 by Algeria, and in 1994 by Tunisia and Turkey. Jordan had a higher rate in the early 80s, which has deteriorated afterwards up until 1992, and then became higher again in 1995 .

\section{REFERENCES}

Agosin, M.R., and Mayer, R. (2000) Foreign investment in developing countries : Does it crowd in domestic investment? UNCTAD working paper, 146.

Barro, R, and Sala-i-Martin, X. (1995) Economic growth. McGraw-Hill, Cambridge, MA.

Bernstein, J.I., and Mohnen, P. (1998) International R\&D spillovers between US and Japanese R\&D intensive sectors. Journal of International Economics, 44, 315-338.

Benhabib, J, and Spiegel, M. (1994) The roles of human capital in economic development : evidence from aggregate cross-country data. Journal of Monetary Economics, 34, 143-173.

Blomstrom, M., and Kokko, A. (1995) What explains developing country growth. NBER working paper, 4132.

Blomstrom, M., Lipsey, R., and Zejan, R. (1992) What explains developing country growth. NBER working paper, 4132 .

Borensztein, J., De Gregorio, J., and Lee, J-W. (1998) How does foreign direct investment affect economic growth? Journal of International Economics, 45, 115-135.

Bouoiyour, J., and Yazidi, M. (2000) Productivité et ouverture en Afrique du Nord. Article présenté au colloque international : Ouverture économique et développement, 23-24 juin, Tunis.

Choudhri, E.U., and Hakura, D.S. (2000) International trade and productivity growth : exploiting the sectorola effets for developping countries. IMF working paper, 00/17, February.

Coe, D.T., and Helpman, E. (1995) International R\&D spillovers. European Economic review, 39, 859-887.

Coe, D.T., Helpman, E., and Hoffmaister, A.W. (1997) North-South R\&D spillovers. The Economic Journal, 107, 134-149.

De Gregorio, J. (1992) Economic growth in Latin America. Journal of Development Economics, 39, 58-84.

Dunning, J. (1988) The eclectic paradigm of international production : a restatement and some possible extensions. Journal of International Business studies, 19(1), 1-31.

Dunning, J. (1994) Multinational enterprises and the globalization of innovatory capacity. Research Policy, 23(1), 67-88.

Findlay, R. (1978) Relative backwardness, direct foreign investment, and the transfer of technology : a simple dynamic model. Quarterly Journal of Economics, 92, 1-16.

Glass, A.J., and Saggi, K. (1998) International technological transfer and technology gap. Journal of development Economics, 55.

Greeneway, D, Morgan, W., and Wright, P. (2002) Trade liberalisation and growth in developping countries. Journal of development Economics, 67, 229-244. 
Grossman, G.M, and Helpman, E. (1991) Innovation and growth in the global economy. MIT Press, Cambridge, MA.

Hejezi, W., and Sarafian, E. (1999) Trade foreign direct investment, and R\&D spillovers. Journal of International Business Studies, 30, 491-511.

Helpman, E. (1992) Endogeneous macroeconomic growth theory, European Economic Review, 36,237-267.

Helpman, E., Krugman, P. (1985) Market structures and Foreign trade, Cambridge, MA : MIT press.

Im K.S., Pesaran M.H., and Shin Y. (2003) Testing for unit roots in heterogeneous panels. Jounal of Econometrics, 115, 53-74.

IMF (2003) Algeria Country report, 03/69.

Menegaldo, F. (2002) Intégration euroméditerranéenne et développement des pays du sud et de l'est de la Méditerranée, Thèse de doctorat, Université de la Méditerranée.

Kao C., Chiang, M.H. and Chen, B. (1999) Internatinal R\&D spillovers : an application of estimation and inference in panel cointegration. Oxford Bulletin of Economics and Statistics, special issue, 691-709.

Keller, W. (1998) Are international R\&D spillovers trade-related ? Analyzing spillovers among ramdomly matched trade partners. European Economic Review, 42, 1469-1481.

Krueger, A.O. (1997) Trade policy and economic development : how we learn. American economic Review, $87,1-22$.

Krugman, P. (1985) A "technology gap" model of international trade, in K Jungenfelt and D Hague (eds), Structural adjustment in developed open economies (New York : Dt Martin's Press).

Levine, R., and Renelt, D. (1992) A sensitivity of cross country growth regressions. American Economic Review, 82, 946-963.

Lichtenberg, F., and Van Pottelsberghe, B. (1998) International R\&D spillovers : a comment. European Economic Review, 42, 1483-1491.

Nahru, V., and Dhareshwar, A. (1993) A new database on physical capital stock : methodology and results, Revista de Analisis Economico, 8 (1), 37-59.

Nelson, R., and Pack, H. (1999) The Asian miracle and modern growth theory. Economic Journal, 109(45), 416-436.

Nelson, R., and Phelps, E. (1966) Investment in humans, technological diffusion, and economic growth. American Economic Review, 61, 69-75.

Pedroni, P. (1997) Panel cointegration: Asymptotic and Finite Sample Properties of Pooled Time Series Tests With an Application to the PPP Hypothesis. Indiana University Working Paper, April.

Pedroni, P. (1999) Critical values for cointegration tests in heterogeneous panels with multiple regressors. Oxford Bulletin of Economics and Statistics, 61, 653-670.

Pedroni, P. (2000) Fully modified OLS for heterogeous cointegrated panels. Advances in Econometrics, 15, 93-130, Nonstationary Panels Panel cointegration and dynamic panels, Jai Press.

Phillips, P., and B. Hansen, (1990) Statistical Inference in Instrumental Variables Regression with I(1) Processes. Review of Economic Studies, 57, 99-125.

Reis, A. (2001) On the welfare effects of foreign investment. Journal of International Economics, 54 411427. 
Romer, D. (1990) Endogenous technological change. Journal of Political Economy, 98, 71-102.

Sadik, A.T., and Bobol, A.A. (2001) Capital flows, FDI, and technology spillovers : evidence from Arab countries. World Development, 89 (12), 2111-2125.

Senhadji, A. (2000) Sources of economic growth : an extensive growth accounting exercise. IMF Staff Papers, 47 (1), 129-157.

Sjoholm, F. (1999) Technology gap, competition, and spillovers from direct foreign investment : evidence from establishment data. Journal of Development Studies, 36(1), 53-73.

UNCTAD, World Investment Reports (1991-2003).

Van Pottlesberghe De La Poterie, B. (1998) The Efficiency of Science and Technology Policies inside the triad, thèse de doctorat, Université Libre de Bruxelles.

Van Pottlesberghe De La Poterie, B. and Lichtenberg, F. (2001) Does Foreign Direct Investment Transfer Technology accross borders? Review of economics and statistics, 83 (3), 490-497.

Wang, J.Y. (1990) Growth, technology transfer, and the long-run theory of international capital movements. Journal of International Economics, 29 (1990), 225-271.

$\mathrm{Xu}$, B. (2000) Multinational enterprises, technology diffusion, and host country productivity growth. Journal of Developpement Economics, 62,477-493.

$\mathrm{Xu}, \mathrm{B}$, and Wang, J. (2000) Trade, FDI, and international technology diffusion. Journal of Economic Integration.

Yu, C., and Démurger, S. (2002) Croissance de la productivité dans l'industrie chinoise : le rôle de l'investissement direct étranger. Economie Internationale, 92, 131-164

Zaimi, F. (2002) La productivité globale des facteurs, Ministère de l'économie, des finances, de la privatisation et du tourisme, document de travail $n^{\circ} 76$. 